\title{
The Creative Industry in The Arkaiss Product As One of The Revitalization Efforts of Sundanese Archaic Words
}

\author{
Ade Mulyanah \\ \{Ad_ariell@yahoo.com $\}$ \\ Balai Bahasa Provinsi Jawa Barat \\ Badan Pengembangan dan Pembinaan Bahasa \\ Ministry Education, Culture, Research, and Technology
}

\begin{abstract}
The Sundanese language as the local language with a large speaker has a significant influence on society. However, several studies show that more Sundanese words are getting archaic. Therefore, it needs revitalization efforts to save them. This study aims to describe the creative industry in the Arkaiss product as one of the revitalization efforts of Sundanese archaic words. The method of the research uses a qualitative descriptive approach. The data collection technique is a survey using questioners and interviews. The result reveals that the Arkaiss consumers' profile is the age range 18-40 years old $(75.9 \%)$, Sundanese ethnic group $(87 \%)$, and university students as the profession $(51,9 \%)$. The respondents' impressions of the archaic words are interesting $(88.9 \%)$, culturally valuable $(88.9 \%)$, and unique $(77.88 \%)$. The findings show the revitalization effort in the creative industry gives good results in socializing the values of language and culture and in preserving the local language.
\end{abstract}

Keywords: Industry creative-1; archaic Sundanese-2; revitalization-3

\section{Introduction}

The Sundanese language spread in West Java, Banten, and on the border of West Java and Central Java has its characteristics. From the observations and research of experts, the Sundanese language that grows and develops in Banten Province, for example, which is a geographical variation, is unique due to the contact between regional languages there cited in Sudarman et.al [2]. We can observe the variation in the Sundanese language used by the Baduy ethnic group in Lebak. The diversity and uniqueness of the Sundanese language is an extraordinary asset that requires protection from the community and the central and local governments. However, the development of civilization in the Sundanese region has increased the cultural mixture, leading to the loss of Sundanese words.

An observation of the loss of the word explains that the emergence of the modern rice cooker has eliminated about fifty Sundanese vocabulary. The vocabulary includes nyangu, nyepan, ngarihan, ngisisi, ngakeul, and ngabibis. Several investigations done by Sobarna [2] 
[3] [4]strengthen this fact by tracing vocabularies in Sundanese that the society rarely uses, such as dulang, hihid, ngakeul, nyengsreng, pangarih aseupan, boboko, and suluh. The finding reveals that the Sundanese people prefer modern tools from various popular products, domestic and foreign, compared to the names of traditional tools. The case of the rice cooker is proof. The technology that continues to emerge is predicted to eliminate more Sundanese vocabulary. The emergence of technology leads to the loss of words called archaic.

One of the efforts to save the Sundanese language is by conducting a revitalization program. Language revitalization is an effort to create specific new forms and functions of an endangered language. The revitalization is intended to increase the use of the language. Even if it is possible, the number of speakers of the language also increases. According to Lauder [5], there are 169 languages that are threatened with extinction in Indonesia. Even with such a large number of threats, we do not yet have a strong preservation program and tradition to save it from extinction, except only at the level of documentation through individual research, universities, or the National Language Center. The data can be used as a reference to find a solution by conducting a revitalization program. The planned revitalization includes expanding the linguistic system of a minority language and creating a new realm of use by new types of speakers. We can do revitalization to save the loss of words or language. The words or language no longer used are called archaic.

According to Kamma [6], language maintenance is an effort made by speakers or those interested in a language to function to meet the needs of its speakers or interested parties. The government has made some efforts to save endangered languages by conducting language revitalization. Revitalization is the process of increasing the vitality of a language that is threatened with extinction so that it has the power to protect language, develop language, and foster language speakers. This revitalization effort is to reveal the phenomenon of the extinction of a local language. The extinction was initiated by a decline in the number of speakers due to language competition. It is also because of the decreasing loyalty of speakers in using their local languages as their mother tongue. Although Sundanese is the second most spoken language after Javanese in Indonesia, the threat of disappearing and unpopularity with the Sundanese word becomes possible. BPS data (2015) shows that there are around 42 million Sundanese native speakers. Sundanese, as one of the local languages, is entering a critical condition. It is due to increasingly intense language competition and the onslaught of increasingly advanced science and technology developments. In general, Sobarna [7] stated that Sundanese is included in the eroding stage or is in a stable condition although threatened with extinction. The death of language in the world has been getting more and more prominent lately, and Sundanese is no exception. The issue is related to the phenomenon in urban centers in West Java, especially Bandung. The people, especially the younger generation, are reluctant to use Sundanese in their daily lives. This phenomenon is interesting to study from the point of view of language death. Therefore, comprehensive strategic efforts are needed to defend the Sundanese language from extinction. One of the efforts to deal with the extinction is to carry out the revitalization.

Several studies conducted by Ewing [8], [9], [10] highlighted that In Indonesia, data on language extinction, especially related to language shift, shows the most crucial symptom of language shift and language vitality. These symptoms include the number and quality of the domains in which it is used and transmitted. The second thing about the threat of language is the loss of transmission from one generation to the next. The phenomenon is now happening in many communities in Indonesia where children no longer speak the language of their parents. There are factors related to social changes in Indonesia, such as economic, educational, and political discourse, that trigger a shift from local to the dominant language. 
How to maintain the language? Cohn [11], [12], [13] expressed his concern about the use of Indonesian as the national language, which would threaten the existence of regional languages. Indonesian as the official language in various fields of state and official areas can continue to erode local languages among the people. The Javanese language as the language with the most speakers is still a concern because of developments. Indonesia, as a multilingual nation, will it continue like that? Or it will likely be a country that only uses the monolingual Indonesian language.

Regarding the development of the Sundanese language, Sobarna [14] investigated the condition of the Sundanese language in teenagers Bandung. In general, teenagers in big cities like Bandung prefer to use foreign languages and Indonesian languages. We must follow up on the challenge immediately. Big cities as multicultural societies are similar to cultural acculturation tourist areas. This condition is not surprising in the multilingual urban. Djajasudarma [15] explained that the acculturation of Sundanese and non-Sundanese languages occurred in tourist areas in Pangandaran. Therefore, Dardjowidjodjo [16] emphasized that various strategies should be made related to using the national language.

One of the efforts to overcome the extinction of languages from both archaic vocabulary and wording threatened with extinction is to do documentation. Penfied [17] made efforts to document endangered languages. The research covers the gap between documenting and revitalizing endangered languages. To deal with the problem of language extinction, We must carry out various documentations that focus on the study of language extinction. The form of the effort is, among others, training that focuses on applied research on endangered languages. However, in revitalizing Grenoble[18] stated that it is necessary to foster motivation. The effort is to promote the psychological connection of people in loving their language by knowing their ancestors, the past life of their people, and their cultural heritage. The effort can have a good impact between the revitalized language and the community concerned. It can build the community and their cultural knowledge and understand the benefits of education about their mother-tongue multilingualism. Some cases related to revitalization is more crucial in border areas. Sundanese regions are within the borders, like Brebes district. Junawaroh [19], [20], [21], [22], [23] believes that we should carry out the revitalization efforts $\mathrm{s}$ in border areas, like in Brebes. As a border area, most of the people, in general, have passive Sundanese language skills. If we do not do it immediately, it will not be easy to maintain the Sundanese language in the area.

The revitalization program has been done in some government efforts by doing research, socialization, raising awareness among the society, and performing it in the creative industry. However, carrying out revitalization programs through the creative sector has been done much. Global competition requires regions to be able to produce output efficiently to survive. Efficiency triggers creative thinking, which in turn can lead to creative ideas. The relative economy, identical to the creative industry, is currently considered a significant contribution to the regional economy.

Furthermore, its existence is an inseparable part. The creative industry contributes significantly to the country's economy, namely an increase in the value of exports, absorption of large numbers of workers, and a contributor to gross domestic product (GDP). Nurchayati \& Ratnawati [24] stated that the contribution of the creative industry to GDP from 2002 to 2006 averaged $6.3 \%$ or equivalent to 152.5 trillion in rupiah. The creative industry can absorb up to 5.4 million workers with a participation rate of $5.8 \%$, meanwhile, in terms of exports, industry.

To increase public attention to local languages, the author tries to collaborate between the two, namely utilizing entrepreneurship to propagate linguistic values, especially Sundanese. 
The chosen field of entrepreneurship in the creative industry is based on language and literature. Creative industries based on language and literature can take the form of T-shirts, bags, stickers, hats, and sweaters, which contain word processing and literature. The word processing can be in the form of standard and non-standard words, motivational words, poetry, and rhymes. The alternative of business can socialize the values of language and literature in it.

The language and literature can express beautiful words, entertainment, advice, cultural values, and various forms of communication for the users. They also can be a form of the creative industry. Why should it use the local language? Because local language is a part of local wisdom. To maintain the local language means to preserve local wisdom. We can do the preservation with the creative industry. The creative sector through Sundanese needs investigating because Sundanese is a regional language with many speakers. These speakers do not realize that the Sundanese language has started to become unpopular. This unpopularity is called words become archaic. Long-term archaic phenomena may lead to the extinction of a language. Therefore, making a product that popularizes the Sundanese language can help reduce the archaic Sundanese words and maintain local wisdom.

The creative industry in Indonesia is currently in the spotlight because it contributes significantly to the economy in Indonesia; based on BEKRAF data, the contribution of the creative economy to Indonesia's gross domestic product in 2017 is $7.28 \%$. According to several sources, we need to consider what the creative industry sees as this considerable contribution. According to BEKRAF, there are 16 creative industry sub-sectors. The followings are application and game development, architecture, product design, fashion, interior design, visual communication design, performing arts, film, animation and video, photography, craft, culinary, music, publishing advertising, fine arts, television, and radio.

Simatupang [25] argued that the creative industry is an industry that relies on skills, talents, and elements of creativity that have the potential to improve welfare. According to the Ministry of Trade of the Republic of Indonesia in 2009, the creative industry utilizes individuals' skills, creativity, and talents to create prosperity and employment opportunities. This industry will focus on empowering the invention of an individual. The creative industry is one sector to support national economic growth. Some of the benefits of developing the creative industry in Indonesia are increasing, opening, and adding jobs, the value and quality of a product are increasing, people will be demanded to be more creative, competitive competition, economic growth.

This study provides an overview of alternative forms of business that can be used to socialize and propagate the values of the language in it. Hilaliyah \& Anam [26] described that the audience of creative industries such as T-shirts, bags, stickers, hats, and sweaters of this kind is dominated by teenagers. Adolescence is an age stage that is thirsty for knowledge. In addition, people of various ages will be more interested when reading the readings of the creative media used. Therefore, this alternative is considered to potentially raise public awareness of the Indonesian language by utilizing entrepreneurship.

Excavation and discussion of the creative industry in linguistics open up opportunities for growth and development of creative industries based or capable of supporting the Indonesian language. These various creative industries use accurate data by the field of work in the sector concerned. Research findings become the primary material for the innovative team in producing innovative industry products that are quality and competitive in the national market, even in the international market. According to Sugono [27] [28] and Lauder [29], Indonesianlanguage products to the global market also expand the distribution. People in today's life need media, such as advertisements (written, audio, and audiovisual), word processing, signboards, 
banners, directions (traffic, roads, tours), warnings, appeals to launch their industrial goals. All of this is presented with the medium of language. It is called the Indonesian language-based creative industry. Based on the facts above, the research aims to find out three objectives. The first goal is to describe the mapping of Arkaiss customers to realize the archaic Sundanese language revitalization program. The second one represents the archaic words used in the Arkaiss Product and the creative industry based on language and the respondents' impressions towards words used in Arkaiss products.

Based on the facts above, there is not much research to investigate revitalization programs using the creative industry. Some Sundanese words have become archaic due to the developments of technology. Hence, the study is intended to describe how the mapping of Arkaiss customers as a revitalization program, what archaic words are used in the Arkaiss products, and respondents' impressions towards the names of Arkaiss products taken from Sundanese archaic words.

\section{Methodology}

\subsection{Method}

This research uses the qualitative descriptive method. The data are taken from questioner using a google form and interviews. There are 54 respondents of this research chosen purposively. They are Arkaiss' customers or parties that have known Arkaiss products through social media, socialization programs, and other media to 54 respondents.

\subsection{Data Collection Technique}

The research gained the data from questioner in the google form. The questioner consists of three parts: respondents' profile, respondents' knowledge of Arkaiss (names of Sundanese archaic words and types of products), and respondents' impressions toward the naming of Arkaiss products. There are ten questions for each part. The questions are related to their knowledge of Arkaiss products names. The description of the respondents' profile contains sex, age, ethnic group, and level of education. The questions are about the names of Arkaiss products in bags, T-shirts, and maskers equipped with archaic words representing the products.

\subsection{Data analysis}

The data analysis is done by calculating the data from google form using Microsoft Excel. The steps of processing the data are analyzing, calculating, and interpreting them. After calculating, they are shown in the form of bar diagrams and pie diagrams. The data is interpreted in the discussion section.

\section{Results and Discussions}

The findings of this study are divided into three parts: the mapping of Arkaiss customers as the products users, the products and words of the archaic that are in demand, and the popularity of Sundanese archaic words. 


\subsection{Results}

\subsubsection{The mapping of Arkaiss Customers}

Based on the results of the data survey, there were 54 respondents. Fifty-four respondents are Arkaiss consumers. Arkais products can be seen from Arkaiss customer profiles. Here is the profile of Arkaiss customers.
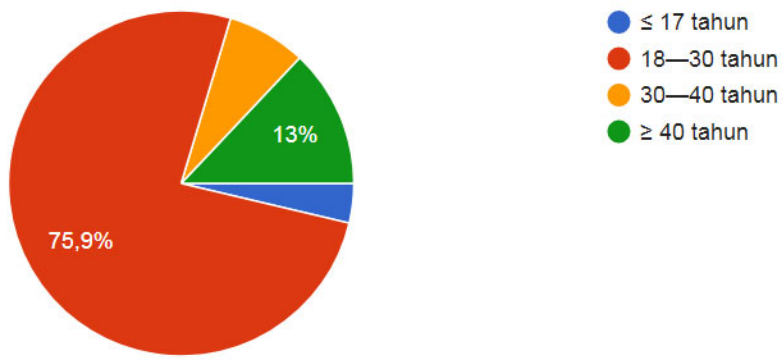

Fig. 1. Composition of respondents by age

The data is intended to see the age range interested in the creative industry based on regional languages. The age range is users aged $18-30$ years $(75.9 \%)$ and $13 \%$ age range 40 years $(13 \%)$, and the rest are aged $30-40$ years. This information can be found in figure 1 .

In figure 2, apart from the age variable, the revitalization program through the creative industry is also seen based on ethnic groups. This data shows that the popularity of the industry product is the Sundanese (87\%), Javanese (9\%), and from other ethnicities. From the data, we know that most of the respondents are Sundanese. It means the goal of the revitalization program of Sundanese archaic words is successful. It is essential to see that this Arkaiss innovative product revitalization program can effectively revive Sundanese words that have become unpopular.

\section{Respondents based on Etnics Group}

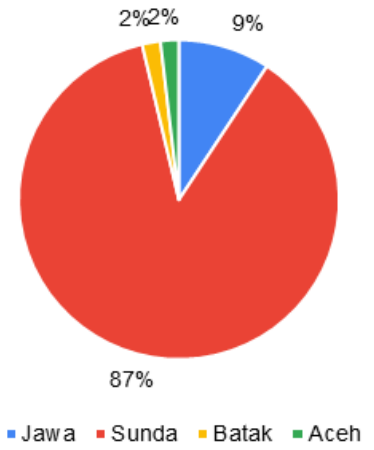

Fig.2. Respondent based ethnics group 
Figure 3 provides an overview to see Arkaiss consumer groups. The data is used to see if this product is liked by students $(51.9 \%)$, civil servants $(16.7 \%)$, private employees $(9.3 \%)$. The rest are from various other professions. This revitalization program was successful because of the enthusiasts of creative industry products from words that Arkaiss already wrote. This data is essential to get an idea of what the creation of Archaic words is.
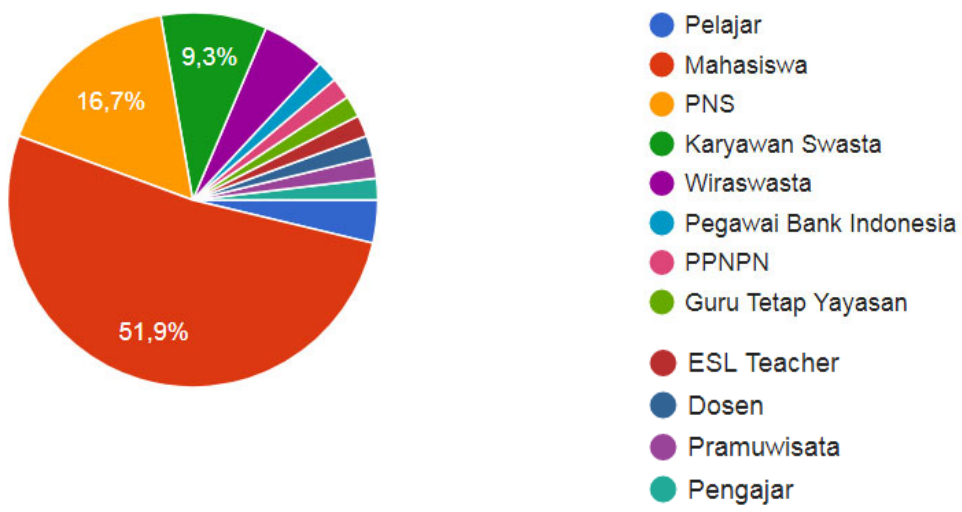

Fig.3. Arkaiss Customer based on education

\subsubsection{Arkaiss Products}

The creative industry will be popular with products known by the public. Product effectiveness related to Arkaiss product Producing can be seen from a survey of Arkaiss consumers. These words can be used to revitalize words that have begun to be unknown to the public. The following are the results of a survey of respondents.
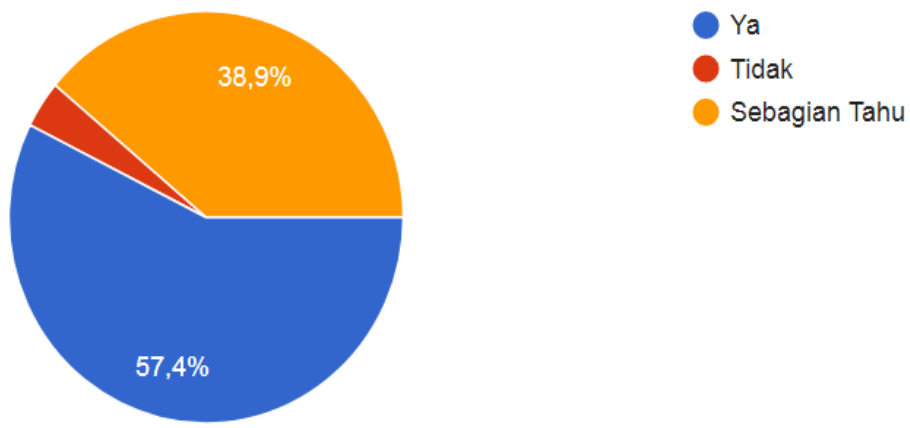

Fig. 4. Arkaiss Product by respondents knowledge

According to the survey results, 57.4\% of consumers claimed to know Arkaiss products, and $39.9 \%$ said that some of the product names knew and the rest did not know and claimed to buy because of the shape, not the naming of words in the Arkaiss product.

From these data results, respondents know that the creative industry product is the archaic words related to vocabularies, such as time markers, pandemics, and women's fashion. The 
product is packaged into the creative industry based on language in the T-shirts, bags, masks, and bags. Respondents prefer products and product names for bags (94.4\%), T-Shirt products $(81.5 \%)$, and masks $(66.7 \%)$. Figure 5 will show more response data.

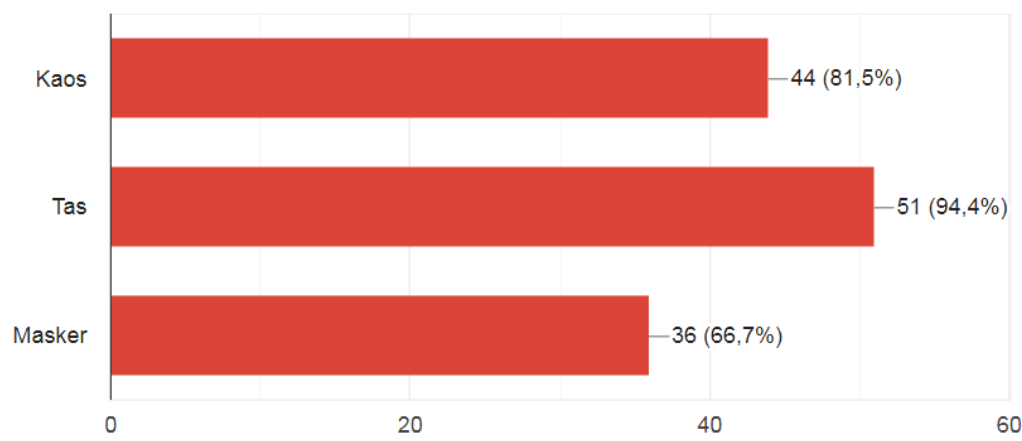

Fig.5. Arkaiss products

Figure 6 shows the data showing the popularity of the words in each product. Every Arkaiss product has a meaning as product Producing and the socialization of Arkais Sundanese words, which are socialized through Arkaiss products. The following are the results of the survey. This survey is to describe whether respondents know the meaning of each word in Arkaiss products. Figure 6 shows the respondents' knowledge of Arkaiss products. From the data, it was found that the words Janari (90.7\%), Sareupna (87.0\%) Jalu $(85.2 \%)$ and Campernik $(81.5 \%)$ are the most popular words among respondents. The words Umpi $(25.9 \%)$ and Kandaga $(33.3 \%)$ are less popular.

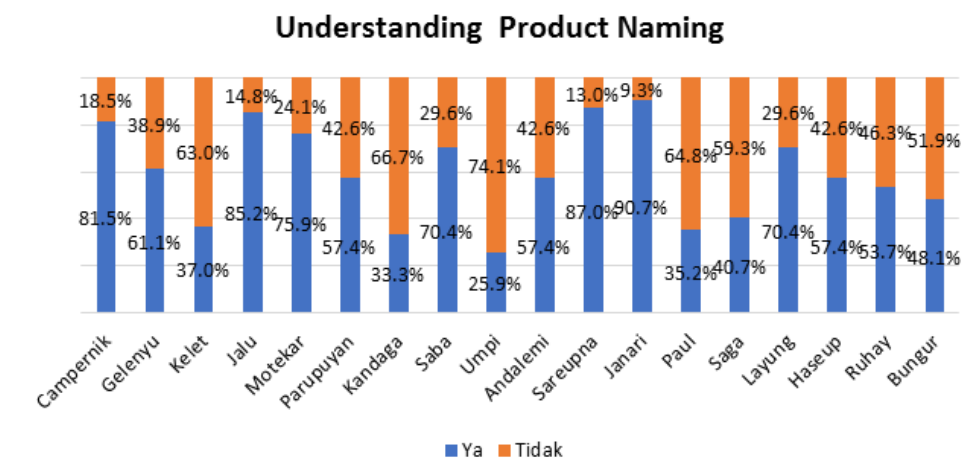

Fig.6. Understanding product naming

\subsubsection{Respondents' Impression toward Sundanese Archaic Words.}

From the survey results, it can be seen that each word for Arkaiss product has a different impression. Respondents gave positive ratings for product names with Arkaiss words. We can see the results of the data analysis in Figure 7. 


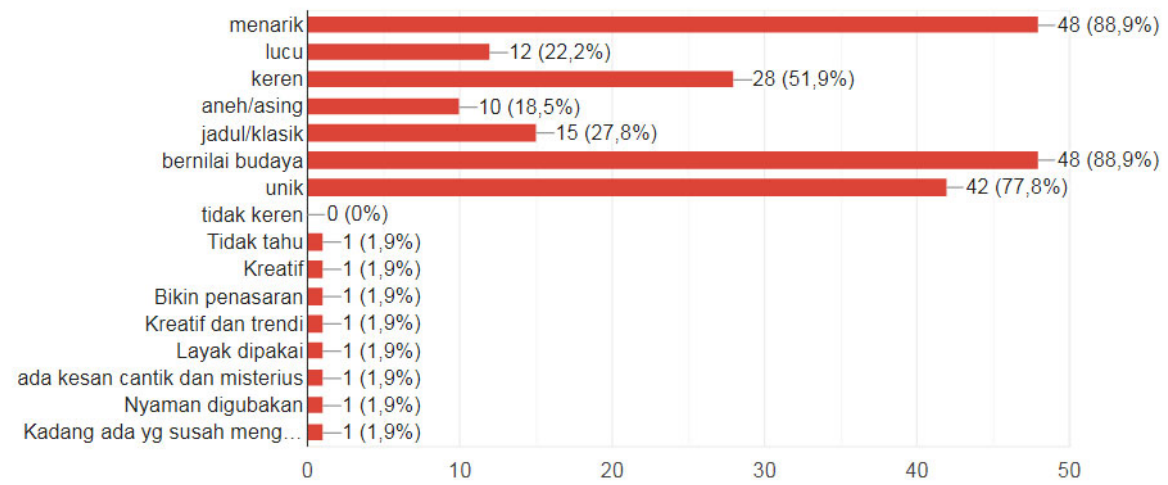

Fig.7. Respondents' impression toward Sundanese archaic words

Based on the survey results obtained positive data about the archaic words used in the product. Respondents stated that mentioning the names of archaic products was interesting $(88.9 \%)$, culturally valuable $(88.9 \%)$, and unique $(77.88 \%)$. This shows that the respondents consider that the naming using Sundanese archaic words has a positive value. Although some respondents think these words are rarely used, the wording of the product is pretty cool $(51.9 \%)$, vintage $(27.5 \%)$, and funny $(22.2 \%)$.

\subsection{Discussion}

\subsubsection{Survey Reveal and Revitalization Efforts}

Based on the survey results, Arkaiss' creative industry products seem to have reached the right group because the archaicism of a language occurs when the language is not popular among young people. The age range of most Arkaiss customers is 18-40 years old (75.9\%). They are from Sundanese (87\%). Their occupations are students $(55,9 \%)$. The broad range of work among the young Sundanese people turns out to be a reasonably significant age mapping. This revitalization target is quite effective. Based on the map of age, occupation, and ethnic groups. The dissemination of archaic words among young people has given positive results.

The findings can solve problems related to the difficulty of involving the young generation to know archaic words. The Arkaiss products have attracted the younger generation by introducing them to bags, T-shirts, and maskers developments. The important thing that needs to be known and realized by all parties with local culture and language is the issue of inheritance. Rosidi (2006) argues that this inheritance is related to the inheritance of skills and appreciation to the younger generation. Culture, including art, without appreciation, will eventually become extinct. Concerning the Sundanese language, Wahya and Adji (2016: 8182) argue that the problem of intergenerational transmission is one of the factors of the lack of success in teaching Sundanese in West Java. Parents, especially those who live in urban areas, rarely invite their children to speak Sundanese. Thus, the creative industry done by Arkaiss product can reduce the probability of these words being archaic

Similarly, children speak Indonesian more often when talking to friends, teachers, and school caretakers at school. It turns out that school attendance cannot be an optimal place to 
learn regional languages without the participation of parents and the community. The same thing can happen in big cities, including in Bandung. Parents and the community must consciously assist their children in learning the local language because it is their responsibility. Therefore, revitalization programs in Arkaiss product can attract young people to know the Sundanese vocabulary in the form of T-shirt, bags, and maskers. Those archaic words are intended to be revitalized by introducing the products in the creative industry.

Vocabularies popularized by Arkaiss include words related to time markers, pandemics, and women's fashion. Some products use the words for T-shirts, bags, and masks. This type of product is undoubtedly popular among young people. The understanding of Sundanese archaic vocabulary words is effective because the respondents remember the words quite well. The data shows the words janari $(90.7 \%)$, sareupna $(87.0 \%)$, jalu $(85.2 \%)$, and campernik $(81.5 \%)$ are the most popular words among respondents. Those words begin to be known again through this revitalization program. The Unesco report states that only $30 \%$ of the world's languages undergo intergenerational transmission shows that $70 \%$ of the world's languages do not experience intergenerational transmission. This means that $70 \%$ of the world's languages are threatened with extinction. This should get the attention of the world community. Therefore, efforts to develop, foster, and protect Sundanese language and culture in various regions must be carried out immediately under the umbrella of local central government policies before Sundanese is not recognized in the lives of children as the next generation.

Raising public awareness to use Sundanese is not an easy thing because it involves attitude issues. Various efforts need to be made at school, at home, and in the community to foster a positive attitude in the Sundanese language. The Sundanese archaic words were not only remembered by the respondents but also gave a reasonably positive impression among them. Based on the survey results obtained positive data about the archaic words used in the product. Respondents stated that mentioning the names of archaic products was interesting $(88.9 \%)$, culturally valuable $(88.9 \%)$, and unique $(77.88 \%)$. The data shows that the linguistic campaign through the creative industry has proven to be effective in revitalizing an archaic vocabulary. The word will begin to be recognized again as the preservation of local wisdom.

Indonesian, which has a broader function than regional languages, sociolinguistically has higher prestige than regional languages. Introducing archaic words to the younger generation is one of the efforts to revitalize Sundanese archaic words. It is natural for speakers of local languages to switch to being Indonesian speakers. However, the switch cannot be tolerated. Regional languages as regional cultural treasures, national culture, and even world culture, which are rich in regional cultural values and characters, must be continuously used.

\subsubsection{The Implication of Language Learning for Revitalization Efforts}

Based on the results of the analysis, we can relate the revitalization efforts to language learning. We can carry out various ways by referring to learning theory. Firstly, we have to introduce archaic words to the students. The most significant step that we should do understand the characteristics of learners. Parlindungan [30]investigated Indonesian culture how we used cultural elements in learning-learning the words of the Indonesian Sundanese cultural archaic on the importance of inclusive representations. Indonesian culture, in general, students are more silent, especially in minority groups. This study suggests that local culture must be included in the teaching materials in the preparation of teaching materials. Concerning the revitalization of the Sundanese archaic vocabulary, perhaps words that are 
already known by the respondents and contain high cultural values related to the pandemic, Tshirts, and bags can be included in teaching materials for local language content.

Secondly, archaic consumers are dominated by teenagers and adults. In the revitalization effort by incorporating elements of Sundanese culture with attractive packaging. We can make revitalization efforts by motivating students. Amirullah [31] explained how to encourage students who are multicultural and generally bilingual or multilingual. Although it is not very similar in form to this study, we can adapt the methodology in this finding, namely the way to introduce the Sundanese archaic vocabulary by motivating unfamiliar language to become prestigious. In naming Arkaiss products, several vocabularies are acceptable for young speakers. They think that the vocabulary is interesting. The findings of this study indicate that these efforts have contributed to them becoming multilingual and multicultural individuals. Referring to this, we can say that revitalization can be used to become multilingual and multicultural.

Thirdly, we can introduce Arkaiss products with more exciting media, for example, developments in the form of proverb writing. Par-Angin [32] examines how proverbs in the culturally literary text deserve to be preserved or protected. Proverbs generally contain a moral message conveyed in interesting figurative words so that it can be used as a medium for socializing archaic products. Product naming not only use words/phrase but also in the form of a proverb. These proverb expressions can be written on T-shirts as a result of the creative industry. Thus, it can be used as a medium for revitalizing the Sundanese language.

Finally, the analysis results show that the vocabulary in the Arkaiss product is quite acceptable in young Sundanese speakers. We can carry out the revitalization efforts by using the context of these words with interesting teaching materials in school materials to develop local language teaching materials. Castro [33] found that learning vocabulary in the second language (L2) must look for familiar vocabulary with the first language. Learners can use vocabularies that have the same semantics. There is an Arkaiss Sundanese vocabulary. The words are familiar in the first language (L1) or languages known to learners, such as Paul, Janari, and Campernik.

\section{Conclusion}

The result of the study indicates significant findings. Firstly, the mapping of Arkaiss consumers shows in the age range, ethnic group, and occupation. Most Arkaiss customers are $18-40$ years old $(75.9 \%)$. They are from Sundanese (87\%). Their occupations are students (55, 9\%). The archaic words used in the Arkaiss Product are related to vocabularies, such as time markers, pandemics, and women's fashion. The associated terms are in some products, such as T-shirts, bags, and masks. Based on the survey results obtained positive data about the archaic words used in the product. Respondents stated that mentioning the names of archaic products was interesting $(88.9 \%)$, culturally valuable $(88.9 \%)$, and unique $(77.88 \%)$.

The socialization of Sundanese archaic vocabulary can be revitalized through linguistic campaigns using creative industries. The research still requires more comprehensive analysis, namely, exploring many aspects from various perspectives and studies.

\section{References}


[1] Sudarma. et.al. Upaya Pemertahanan Bahasa-Budaya Sunda di Tengah Pengaruh Globalisasi. Jurnal Unpad. (2018)

[2] "Basa Sunda dina Kahirupan Kiwari: Hudang Gering atawa Ciri Kamoderenan?". Makalah

Kongres Basa Sunda VII, Garut, 10-12 November (2001)

[3] "Pemeliharaan Bahasa Ibu: Sebuah Upaya Memperkukuh Jati Diri". Makalah Hari Bahasa Ibu Internasional, Universitas Padjadjaran, Bandung 21 Februari (2007).

[4] Kehidupan Bahasa Sunda di Lingkungan Remaja Kodya Bandung. Jakarta: Pusat Bahasa (1997)

[5] M. Lauder. 169 Bahasa Daerah Terancam Punah. (online). Tersedia: nasional.kompas.com/read/2008/8/11/21544654/169.bahasa.daerah.terancam.punah.(20 08)

[6] A. Kamma. Usaha pemertahanan dan revitalisasi bahasa ponosakan the retention and revitalization of ponosakan language. (2016)

[7] C. Sobarna. Bahasa Sunda Sudah Di Ambang Pintu Kematiankah? Makara, Sosial Humaniora, Vol. 11, No. 1, Juni . Pp 13-17. Universitas Padjadjaran. (2007)

[8] M.C. L. Ewing. M.C. Language Endangerment In Indonesia. International Journal of Education VoL 8, No.1 (20) December ( 2014). [Online serial]. Available: https://ejournal.upi.edu/index.php/ije/article/view/1764/1210 [Accessed September 2, $2021]$.

[9] Grammar and inference in conversation: identifying clause structure in spoken Javanese. Amsterdam: John Benjamins (2005)

[10] Agentive alignment in Central Maluku languages, in Michael C. Ewing and Marian Klamer (eds.) East Nusantara: Typological and Areal Analyses, 119-141. Canberra: Pacific Linguistics (2010)

[11] A.Cohn, and M. Ravindranath. Local Languages in Indonesia: Language Maintenance or Language Shift? Jurnal Masyarakat Linguitics Indonesia Linguistik Indonesia Vol 32, No 2 (2014). Available at http://ojs.linguistik indonesia.org/index.php/linguistik_indonesia/article/view/22

[12] et.al. 2013. Kuesioner Penggunaan Bahasa Sehari-hari. Available at http://lingweb.eva.mpg.de/jakarta/kuesioner.php. (2013)

[13] et.al. . "Assessing the impact of Indonesian on the maintenance of local languages." Presented at KIMLI (2014), Lampung, Indonesia.(2014)

[14] C. Sobarna, et.al. Kehidupan Bahasa Sunda Di Lingkungan Remaja Kodya Bandung. Jakarta: Pusat Pembinaan dan Pengembangan Bahasa, Departemen Pendidikan dan Kebudayaan. (1997)

[15] F. T. Djajasudarma, T. Fatimah. Akulturasi bahasa Sunda dan non-Sunda di daerah pariwisata Pangandaran, Jawa Barat. Jakarta: Pusat Pembinaan dan Pengembangan Bahasa, Departemen Pendidikan dan Kebudayaan.(1994).

[16] S. Dardjowidjodjo, Soenjono. "Strategies for a successful national language policy: The Indonesian case." International Journal of the Sociology of Language pp. 35-47. (1998).

[17] S. D. Penfield and Benjamin V. Tucker. From documenting to revitalizing an endangered language: where do applied linguists fit? JournalLanguage and Education. International Languages, Literatures and Cultures, School of Original languageEnglish (US) Volume25. Issue number4. July. Pp Pages 291-30 StatePublished - Jul 2011 https://arizona.pure.elsevier.com/en/publications/from-documenting-to-revitalizing-anendangered-language-where-do- 
[18] L. A. Grenoble. Why Revitalize? rom Part I - Planning to Revitalize Published online by Cambridge University Press: (2021) https://www.cambridge.org/core/books/revitalizing-endangered-languages/whyrevitalize/1B2E8278917584D01F975A09ABF56AF7

[19] S. Junawaroh, C. -. Sobarna, W. -. -, and S. -. Riyanto, "Sundanese Language Maintenance Based on The Heterogeneity of The Speakers," PAROLE: Journal of Linguistics and Education, vol. 10, no. 2, pp. 136-145, Oct. 2020. https://doi.org/10.14710/parole.v10i2.136-145 http://creativecommons.org/licenses/by$\mathrm{sa} / 4.0$.

[20] Pemertahanan Bahasa Sunda di Kecamatan Bantarkawung Kabupeten Brebes. Metalingua; Jurnal Penelitian Bahasa.Vol. 6 Juni (2008)

[21] (2016). Deskripsi Perbedaan Fonologi Bahasa-Bahasa di Wilayah Barat Provinsi Jawa Tengah. Humanika. Vol. 23 No. 2, 1-8. (2016).

[22] \& A. Hidayat,(2013). Leksikon Bahasa Jawa dalam Bahasa Sunda di Kabupaten Brebes. Adabiyat; Jurnal Bahasa dan Sastra.Vol. XII No.1, 101-115 (2013).

[23] \& Kulsum, U. (2010). Penelitian Kekerabatan dan Pemetaan Bahasa Bahasa-bahasa di Kabupaten Brebes. Laporan Penelitian Riset Unggulan Daerah (RUD) Kabupaten Brebes (2010)

[24] Nurchayati \& Ratnawati. Strategi Pengembangan Industri Kreatif Sebagai Penggerak Destinasi Pariwisata di Kabupaten Semarang. Prosiding Seminar Nasional Multi Disiplin Ilmu \& Call For Papers Unisbank (Sendi_U) Ke-2. (2016)

[25] Simatupang. Perkembangan Industri Kreatif. Jurnal Institut Teknologi Bandung. (2007) Accessed in Unsyiah.ic.id.

[26] Hilaliyah \& Anam.”Alternatif Industri Kreatif Berbasis Bahasa Dan Sastra Indonesia".Diskusi Panel Nasional Pendidikan Kewirausahaan LPPM Universitas Indraprasta PGRI Jakarta, ISBN : 978-602-50181-0-7. Jakarta. (2017)

[27] Sugono. D. Peran Dan Kekuatan Bahasa Indonesia dalam Industri Kreatif Kebahasaan. ISBN 978-979-069-169-8. Badan Pengembangan dan Pembinaan Bahasa: Jakarta (2014)

[28] "Pengembangan Industri Kreatif Daya Dukung Bahasa". Seminar Pengembang Industri Kreatif Berbasis Media, Teknologi dan Iptek, Yogyakarta. (2012)

[29] M. Lauder. "Optimalisasi Bahasa Indonesia Berbasis Korpus Linguistik”. Makalah Pertemuan Ilmiah Bahasa

[30] F. Parlindungan1.et.al.The representation of Indonesian cultural diversity in middle school English textbooks. Indonesian Journal of Applied Linguistics Vol. 8 No. 2, September 2018, pp. 289-302 Available online at: http://ejournal.upi.edu/index.php/IJAL/article/view/13276.

[31] A. Amirullah. Portraits of Graduates in Becoming Multilingual and Multicultural Citizens in the Context of Internationalization. International Journal of Language Education Volume 5, Number 2, 2021, pp. 116-124. ISSN: 2548-8457 (Print) 25488465 (Online) Doi: https://doi.org/10.26858/ijole.v5i2.21937

[32] D. M. Perangin-Angin and Novita Dewi. A study of Pagu proverbs: Saving an endangered language of North Halmahera. Indonesian Journal of Applied Linguistics. Vol. 10 No. 2, September 2020, pp. 327-339Available online at: https://ejournal.upi.edu/index.php/IJAL/article/view/28597.

[33] V.G. Castro. The effects of vocabulary knowledge in L2 semantic lexical engagement: The case of adult learners of English as a second language.Vol. 10 No. 1, May 2020, pp. 261-270.Available online 
at:https://ejournal.upi.edu/index.php/IJAL/article/view/25068.https://doi.org/10.17509/i jal.v10i1.25068 